Syntax Idea: p-ISSN: 2684-6853 e-ISSN: 2684-883X

Vol. 3, No.11, November 2021

\title{
MEKANISME KEJADIAN DERMATITIS KONTAK IRITAN AKIBAT PAPARAN BUAH NANAS (ANANAS COMOSUS)
}

\section{Enjelina, Dea Alnisrina, Lulu' Farida}

Universitas Lampung, Sumatera, Indonesia

Email: alegna0315@gmail.com,deaalnisrinagf@gmail.com, lulufarida05@gmail.com

\begin{abstract}
Abstrak
Dermatitis kontak iritan merupakan respon kulit terhadap kontak dengan berbagai paparan zat seperti biologi, kimia maupun fisik. Terjadinya DKI dapat dipengaruhi oleh faktor endogen maupun eksogen. Faktor eksogen seperti paparan zat dari lingkungan sekitar dan faktor endogen seperti fungsi pertahanan kulit dan adanya riwayat dermatitis sebelumnya seperti dermatitis atopik. Literature review ini bertujuan untuk memahami mekanisme terjadinya dermatitis kontak iritan akibat paparan nanas (Ananas comosus) terutama pada pekerja serta pencegahannya. Studi ini dilakukan dengan mengumpulkan sejumlah buku, artikel penelitian dan jurnal ilmiah yang berhubungan dengan mekanisme terjadinya dermatitis kontak iritan akibat paparan nanas (Ananas comosus). Literature review telah dilakukan pada Julì 2019. Nanas atau Ananas comosus adalah anggota dari famili bromeliad dan dikenal sebagai penyebab dermatitis iritan dan stomatitis. Ekstraksi nanas mengandung sejumlah enzim proteolitik yang dikenal sebagai bromelain, yang juga merupakan iritan kimiawi dan fisika termasuk asam sitrat dan kalsium oksalat. Oleh karena itu, buah nanas dapat menjadi salah satu penyebab dermatitis kontak iritan. Mekanisme ini berawal dari paparan ringan hingga terus-menerus menyebabkan distrubsi barier yang menyebabkna aktivasi sitokin serta limfosit $\mathrm{T}$ yang memunculkan gejala berupa inflamasi dan lesi pada kulit.
\end{abstract}

Kata Kunci: dermatitis kontak iritan; mekanisme; nanas; Bromelain

\section{Abstract}

Irritant contact dermatitis is the skin's response to contact with various exposures to substances such as biological, chemical and physical. The occurrence of DKI can be influenced by endogenous and exogenous factors. Exogenous factors such as exposure to substances from the surrounding environment and endogenous factors such as skin defense function and the presence of a previous history of dermatitis such as atopic dermatitis. This literature review aims to understand the mechanism of the occurrence of irritant contact dermatitis due to exposure to pineapple(Ananas comosus)especially in workers and prevention. The study was conducted by collecting a number of books, research articles and scientific journals that deal with the mechanism of the occurrence of irritant contact dermatitis due to exposure to pineapple(Ananas comosus). Literature review has been conducted in Juli 2019. Pineapple or Ananas comosus is a member of the bromeliad family and is known to be the cause of irritant dermatitis and stomatitis. Pineapple extraction contains a number of proteolytic enzymes known as bromelain, which are also

\begin{tabular}{ll}
\hline How to cite: & Enjelina., Alnisrina,D,, L, Farida., (2021) Mekanisme Kejadian Dermatitis Kontak Iritan Akibat \\
& Paparan Buah Nanas (Ananas Comosus) Syntax Idea, 3(11), https://doi.org/10.36418/syntax- \\
& idea.v3i11.1566 \\
E-ISSN: & 2684-883X \\
Published by: & Ridwan Institute
\end{tabular}


chemical and physical irritants including citric acid and calcium oxalate. Therefore, pineapple fruit can be one of the causes of irritant contact dermatitis. This mechanism starts from mild exposure to continuously causing barrier distrubsi which causes the activation of cytokines and T lymphocytes that cause symptoms in the form of inflammation and lesions on the skin.

Keywords: irritant contact dermatitis; mechanism; pineapple; Bromelain

Received: 2021-10-22; Accepted: 2021-11-05; Published: 2021-11-20

\section{Pendahuluan}

Indonesia merupakan wilayah yang beriklim tropis dan berada di daerah khatulistiwa. Indonesia memungkinkan tumbuhnya berbagai macam tumbuh-tumbuhan dengan subur seperti buah-buahan. Buah-buahan mengandung berbagai macam vitamin yang diperlukan oleh tubuh, salah satunya adalah vitamin C. Vitamin C berperan sebagai antioksidan dan efektif mengatasi radikal bebas yang merusak sel atau jaringan (Tayeb Et Al., 2013).

Nanas merupakan salah satu jenis buah yang banyak diminati oleh masyarakat. Bentuknya bulat panjang, kulit buahnya bersisik. Kebutuhan vitamin $\mathrm{C}$ yang dianjurkan adalah sebesar 30-60 mg per hari, sedangkan rata-rata kecukupan vitamin $\mathrm{C}$ untuk keluarga adalah sebesar $(53,7 \pm 2,2)$ mg (Nanas merupakan salah satu jenis buah yang banyak diminati oleh masyarakat. Bentuknya bulat panjang, kulit buahnya bersisik. Kebutuhan vitamin $\mathrm{C}$ yang dianjurkan adalah sebesar 30-60 mg per hari, sedangkan rata-rata kecukupan vitamin $C$ untuk keluarga adalah sebesar $(53,7 \pm 2,2) \mathrm{mg}$ (Karinda et al., 2013).

Dermatitis atau eksim merupakan pola inflamasi kutaneus yang muncul dengan efloresensi eritema, vesikel, dan gatal pada fase akutnya. Pada fase kronisnya ditandai dengan kekeringan, kulit mengelupas, dan terdapat fisura. Dermatitis kontak iritan (DKI) adalah respon kulit terhadap kontak dengan bahan kimia, fisik, atau biologi. Terjadinya DKI dapat dipengaruhi oleh faktor endogen seperti fungsi pertahanan kulit dan adanya riwayat dermatitis sebelumnya seperti dermatitis atopik. Hampir 80\% dari kasus dermatitis merupakan dermatitis kontak iritan dan DKI sering berhubungan dengan pekerjaan (Brasch et al., 2014).

Selama abad keenam belas dan ketujuh belas, tanaman nanas diperkenalkan ke Asia Pasifik dan menjadi tanaman komersial pertama. Bromelain adalah campuran alami kompleks enzim proteolitik yang berasal dari nanas (Ananas cosmosus) dan memiliki sifat terapeutik yang penting. Bromelain telah digunakan selama bertahuntahun dalam pengobatan tradisional untuk berbagai masalah kesehatan. Bromelain berpotensial digunakan sebagai zat terapi karena sifat biokimia dan farmakologinya, dan bahan utama dalam bromelain adalah enzim proteolitik yang disebut glikoprotein, yang merupakan tambahan untuk bahan yang tidak larut, seperti mineral, pigmen berwarna, protease inhibitor, asam organik dan pelarut organik. Sampai saat ini, delapan komponen aktif proteolitik telah diisolasi dari bromelain. Proteinase dianggap sebagai 
fraksi yang paling aktif, yang terdiri dari $\sim 2 \%$ dari total protein. Bromelain memberikan aktivitasnya selama rentang $\mathrm{pH} 4,5$ hingga 9,5. Adalah mungkin untuk mengisolasi dan memurnikan bromelain menggunakan berbagai metode (Rathnavelu et al., 2016). Di balik manfaatnya sebagai zat terapi, kandungan bromelain pada nanas (Ananas comosus) juga dapat menimbulkan dampak negatif seperti dermatitis kontak iritan.

Telah banyak studi kasus yang berhubungan dengan dermatitis kontak iritan pada zat kimia salahsatunya bromelain dan sitrat yàng terkandung dalam nanas. Durasi paparan zat kimia yang cukup lama dan terus-menerus menimbulkan keluhan berupa rasa perih dan gatal-gatal pada daerah yang terpapar walaupun telah dilakukan pencegahan berupa penggunaan sarung tangan keluhan tidak berkurang. Banyaknya kasus yang terjadi terutama pada pekerja pabrik pengolahan nanas dan petani nanas dapat menurunkan kinerja dan produksi.

Penelitian ini dibuat dengan tujuan untuk memahami mekanisme terjadinya dermatitis kontak iritan akibat paparan nanas (Ananas comosus) terutama pada pekerja serta pencegahannya.

\section{Metode Penelitian}

Metode penelitian yang digunakan berupa studi literatur (literature review). Metode ini dilakukan dengan mengumpulkan sejumlah buku, artikel penelitian dan jurnal ilmiah. Pemilihan referensi didapatkan dengan dermatitis kontak iritan, mekanisme, zat kimia , dan bromelain. Referensi yang digunakan berhubungan dengan mekanisme terjadinya dermatitis kontak iritan akibat paparan nanas (Ananas comosus) (Wasitaatmadja, 2018).

\section{Hasil dan Pembahasan}

\section{A. Definisi}

Dermatitis kontak iritan merupakan reaksi kulit terhadap bahan asing eksternal berupa gesekan atau paparan yang menyebabkan iritasi pada kulit. Manifestasi berupa warna kulit kemerahan atau coklat dan dapat disertai papula maupun pustula serta terasa panas. Jika bahan iritan yang terpapar terus menerus dapat menyebabkan kulit kering dan pecah-pecah serta infeksi (Frosch \& John, 2011).

\section{B. Patofisiologi dan Manifestasi Klinis Dermatitis Kontak Iritan}

DKI terjadi setelah paparan tunggal pada substansi yang berbahaya bagi kulit dan pada beberapa kasus berat dapat menimbulkan nekrosis. Hal ini dapat terjadi bergantung pada konsentrasi substansi dan dapat terjadi pada semua orang, bergantung pada kemampuan penetrasi dan ketebalan stratum korneum. Terdapat batas konsentrasi dari substansi-substansi tersebut yang dapat menyebabkan dermatitis akut. Pembeda antara dermatitis kontak iritan dengan dermatitis kontak alergi (DKA), dimana DKA bergantung pada sensivitas dan hanya dapat terjadi pada orang-orang yang sensitif. Karena DKI merupakan efek toksik, gejala yang 
muncul hanya terbatas pada area tubuh yang terpapar sehingga selalu berbatas tegas dan tidak menyebar (Brasch et al., 2014).

Manifestasi klinis klasik yang muncul pada DKI berupa lesi yang terbatas pada area yang terpapar toksin, berbatas tegas pada fase akut, efloresensi bervariasi dimulai dari eritema sampai nekrosis, munculnya gejala bergantung pada keakutan dan toksin, dan wtidak menyebar (Goldsmith et al., 2012). Secara umum patogenesis terjadinya dermatitis kontak iritan dapat dijelaskan sebagai berikut, sistem imun berperan dalam menyebabkan terjadinya dermatitis kontak iritan melalui berbagai jalur. Meskipun begitu, iritan menyebabkan perubahan patofisiologi kulit berupa disrupsi barier, kerusakan epidermis seluler, dan pelepasan mediator proinflamasi yang semuanya saling berkaitan. Keratinosit berperan penting dalam produksi respon imunologis terhadap iritan (Suryani, 2011). Keratinosit melepaskan sitokin pada disrupsi barier kulit, dan mengatur antigen major histocompatibility class II (MHC II) dan molekul adhesi sel. Pelepasan sitokin proinflamasi interleukin- $1 \alpha$, interleukin-1 $\beta$ dan TNF- $\alpha$ oleh keratinosit juga berperan dalam reaksi terhadap iritan. Kemokin, CCL21, yang dihasilkan oleh sel endotel limfatik, mendorong terajdinya migrasi limfosit $\mathrm{T}$, yang menyebabkan respon inflamasi kulit. Limfosit $\mathrm{T}$ yang memasuki daerah yang mengalami iritasi melepaskan antigen CLA. Antigen tersebut berperan langsung pada migrasi transendotel limfosit T. Ligan untuk antigen CLA adalah E-selectin. Pasangan ligan reseptor lainnya, seperti LFA1/ICAM1 dan VLA4/VCAM1, juga terlibat dalam proses ini. Antigen CLA menyebabkan agregasi limfosit T ke daerah inflamasi lokal. Tidak ada sitokin spesifik yang membedakan antara reaksi alergi dengan iritan (Slowdownik D, Lee A, 2008).

\section{Mekanisme Dermatitis Kontak Iritan Akibat Paparan Buah Nanas}

Salah satu etiologi tersering dari dermatitis kontak iritan adalah paparan zat atau senyawa dalam tumbuhan. Reaksi kulit akibat tumbuhan sering terjadi karena tumbuhan melepaskan berbagai bahan kimiawi dan fisik yang dapat membahayakan. Empat tipe reaksi pada kulit akibat paparan tumbuhan atau produk yang berasal dari tumbuhan antara lain adalah dermatitis kontak iritan, urtikaria kontak, dermatitis kontak alergi, dan fitofotodermatitis. Reaksi dermatitis kontak iritan disebabkan oleh salah satu dari tujuh kelompok iritan dasar: kalsium oksalat, protoanemonin, isothiocyanate, diterpene ester, bromelain, dan alkaloid (Modi et al., 2009). Bromelain dan protease sistein adalah enzim yang terdapat pada nanas (Ketnawa et al., 2012). Nanas atau Ananas comosus adalah anggota dari famili bromeliad dan dikenal sebagai penyebab dermatitis iritan dan stomatitis. Ekstraksi nanas mengandung sejumlah enzim proteolitik yang dikenal sebagai bromelain, yang juga merupakan iritan kimiawi dan fisika termasuk asam sitrat dan kalsium oksalat (Belcher et al., 2016).

Aktivitas proteolitik bromelain merupakan sumber iritasi kulit. Hal ini diakibatkan kalsium oksalat pada tumbuhan nanas yang menyebabkan mikroabrasi sehingga bromelain memberikan efek proteolitik pada pembuluh darah dermis. 
Oleh karena itu, hal ini tidak mengejutkan bahwa pekerja pada pengolahan nanas sering memiliki fisura dan kehilangan sidik jari pada tangan mereka (Modi et al., 2009).

\section{Pencegahan Dermatitis Kontak Iritan}

Dermatitis kontak iritan akibat paparan zat atau senyawa dalam nanas, khususnya bagi para pekerja pada pengolahan nanas dapat dicegah dan ditangani melalui beberapa langkah pencegahan (level of prevention).

Pertama, pencegahan tingkat dasar (primordial prevention) dimulai dengan usaha mencegah terjadinya risiko atau mempertahankan keadaan risiko rendah dalam lingkungan kerja yang memungkinkan timbulnya suatu penyakit. Pencegahan bisa dilakukan dengan mempertahankan pola makan dan aktivitas para pekerja. Upaya ini juga bisa dilakukan dengan seleksi awal pada pekerja yang memiliki alergi terhadap nanas atau reaksi iritasi terhadap nanas maupun bahan-bahan lain di tempat pekerjaan (Al-Otaibi \& Alqahtani, 2015).

Kedua, pencegahan tingkat pertama (primary prevention) yang dapat dilakukan dengan beberapa teknik, antara lain:

a. Teknik pengontrolan

Teknik pengontrolan ini meliputi eliminasi, substitusi, dan pemisahan bahan-bahan yang bersifat iritan atau allergen. Langkah subtitusi yaitu mengganti zat yang menjadi alergen dan iritan dengan zat lain yang lebih rendah potensi untuk menimbulkan reaksi hipersensitivitasnya. Pencegahan primer juga dapat dilakukan dengan mendesain tempat kerja sehingga para pekerja dapat bekerja dengan posisi ergonomis (Jeyaratnam \& Koh, 2009).

b. Perlindungan Pribadi

Alat pelindung diri yang dapat menurunkan angka kesakitan dermatitis kontak adalah dengan menggunakan sarung tangan. Penggunaan APD sarung tangan secara benar sangat efektif untuk mencegah penyakit kulit akibat kerja. Jenis sarung tangan yang digunakan sebaiknya disesuaikan jenis iritan yang ditangani dan jenis proses kerja yang dilakukan. Sarung tangan harus menutupi sepertiga lengan baw ah agar efektif penggunaannya (Jeyaratnam \& Koh, 2009). Selain sarung tangan, alat pelindung diri lainnya adalah sepatu bot dan pakaian pekerja yang sesuai dengan mempertimbangkan sifat fisik dan resistensi dari senyaw a yang dihubungi serta kemampuan beradaptasi pekerjanya (Schnuch et al., 2012).

c. Promosi kesehatan

Usaha peningkatan derajat kesehatan (promotion) bertujuan untuk meningkatkan derajat kesehatan perorangan dan kelompok pekerja secara optimal, mengurangi peranan penyebab dan derajat risiko serta meningkatkan lingkungan yang sehat secara optimal.Promosi kesehatan diberikan kepada pekerja baru maupun pekerja lama. Lewat promosi ini dilakukan pengenalan postur tubuh yang baik, cara bekerja yang baik, pengenalan allergen dan bahan iritan. Pekerja juga mendapat informasi tentang gejala dan tanda-tanda dermatitis kontak, metode 
yang tepat untuk menggunakan alat pelindung diri, penggunaan krim khusus penghalang reaksi hipersensitivitas, serta edukasi kebersihan individu dan lingkungan kerja. Promosi kesehatan ini harus dilakukan secara berulangkali (Adisesh et al., 2013).

d. Dukungan motivasi

Motivasi juga penting dalam program pencegahan, namun sering diabaikan. Meskipun sudah diberikan pendidikan kesehatan, beberapa pekerja tidak memperhatikan masih mengganggap hal itu tidak penting karena mereka tidak memandang diri mereka berharga dan penting untuk dilindungi. Upaya memotivasi pekerja dilakukan untuk meyakinkan pekerja, bahwa diri mereka lahyang paling beresiko ketika tidak melakukan pekerjaan tanpa mengikuti prosedur yang ditetapkan. Dalam hal ini peran mandor atau orang yang bertugas mengawasi mereka dalam bekerja sangat besar (Saary et al., 2005).

e. Peraturan yang Jelas

Peraturan tentang kelengkapan penggunaan APD dan label peringatan harus ditempatkan pada semua wadah atau produk di mana bahan kimia berbahaya atau zat lain mungkin ditemui. Bahaya kesehatan harus dijelaskan dengan jelas pada lembar data keselamatan bahan. Tidak hanya itu, harus ada label yang jelas bagaimana tatalaksaana awal apabila terkena bahan kimia tersebut (Johansen et al., 2011).

Ketiga, pencegahan tingkat kedua (secondary prevention) berupa diagnosis awal dan pengobatan tepat (early diagnosis and prompt treatment) untuk mengetahui reaksi kulit pekerja terhadap nanas dan bahan-bahan lainnya. Diagnosis dapat dilakukan dengan pemeriksaan tes patch dan pengujian tambahan dengan alergen yang spesifik untuk mengkonfirmasi alergen yang dapat menyebabkan dermatitis kontak. Screening pra-kerja juga bisa dilakukan untuk menghindari mempekerjakan karyawan baru pada bahaya untuk dermatitis kontak terhadap nanas dan bahan lain yang ada pada proses produksi (Johansen et al., 2011).

Terakhir, pencegahan tingkat ketiga (tertiary prevention) berupa perawatan dermatitis kontak bervariasi berdasarkan stadiumnya. Dalam kasus dermatitis kontak, pencegahan iritasi dan alergen harus diterapkan. Penilaian kerusakan kulit dan kecacatan akibat kerja harus dilakukan. Upaya rehabilitasi bertujuan untuk memulihkan dan memaksimalkan produktivitas pekerja.

\section{Kesimpulan}

Dermatitis atau eksim merupakan pola inflamasi kutaneus yang muncul dengan efloresensi eritema, vesikel, dan gatal pada fase akutnya. Pada fase kronisnya ditandai dengan kekeringan, kulit mengelupas, dan terdapat fisura. Dermatitis kontak iritan (DKI) adalah respon kulit terhadap kontak dengan bahan kimia, fisik, atau biologi. DKI terjadi setelah paparan tunggal pada substansi yang berbahaya bagi kulit dan pada beberapa kasus berat dapat menimbulkan nekrosis. Hal ini dapat terjadi bergantung pada 
konsentrasi substansi dan dapat terjadi pada semua orang, bergantung pada kemampuan penetrasi dan ketebalan stratum korneum. Terdapat batas konsentrasi dari substansisubstansi tersebut yang dapat menyebabkan dermatitis. Etiologi tersering dari dermatitis kontak iritan adalah paparan zat atau senyawa dalam tumbuhan. Reaksi kulit akibat tumbuhan sering terjadi karena tumbuhan melepaskan berbagai bahan kimiawi dan fisik yang dapat membahayakan. Empat tipe reaksi pada kulit akibat paparan tumbuhan atau produk yang berasal dari tumbuhan antara lain adalah dermatitis kontak iritan, urtikaria kontak, dermatitis kontak alergi, dan fitofotodermatitis. Reaksi dermatitis kontak iritan disebabkan oleh salah satu dari tujuh kelompok iritan dasar: kalsium oksalat, protoanemonin, isothiocyanate, diterpene ester, bromelain, dan alkaloid. Bromelain dan protease sistein adalah enzim yang terdapat pada nanas. Oleh karena itu, terdapat hubungan antara paparan buah nanas (Ananas comosus) dengan kejadian dermatitis kontak iritan. 


\section{BIBLIOGRAFI}

Adisesh, A., Robinson, E., Nicholson, P. J., Sen, D., Wilkinson, M., \& Group, S. of C. W. (2013). UK standards of care for occupational contact dermatitis and occupational contact urticaria. British Journal of Dermatology, 168(6), 11671175.Google Scholar

Al-Otaibi, S. T., \& Alqahtani, H. A. M. (2015). Management of contact dermatitis. Journal of Dermatology \& Dermatologic Surgery, 19(2), 86-91. Google Scholar

Belcher, M. D., Kaddour-Djebbar, I., Bollag, W. B., \& Davis, L. S. (2016). The proteolytic effect of bromelain on bullous pemphigoid antigen-2. Journal of the American Academy of Dermatology, 75(4), 838-840. Google Scholar

Brasch, J., Becker, D., Aberer, W., Bircher, A., Kränke, B., Jung, K., Przybilla, B., Biedermann, T., Werfel, T., \& John, S. M. (2014). Guideline contact dermatitis. Allergo Journal International, 23(4), 126-138. Google Scholar

Frosch, P. J., \& John, S. M. (2011). Clinical aspects of irritant contact dermatitis. In Contact Dermatitis (pp. 305-345). Springer. Google Scholar

Goldsmith, L., Katz, S., Gilchrest, B. A., Paller, A. S., Leffell, D. J., \& Wolff, K. (2012). Fitzpatrick's Dermatology in General Medicine, Ed. McGrawHill Medical, 2421-2429. Google Scholar

Jeyaratnam, J., \& Koh, D. (2009). Buku ajar praktik kedokteran kerja. Jakarta: Penerbit Buku Kedokteran EGC, 237-260. Google Scholar

Johansen, J. D., Hald, M., Andersen, B. L., Laurberg, G., Danielsen, A., Avnstorp, C., Kristensen, B., Kristensen, O., Kaaber, K., \& Thormann, J. (2011). Classification of hand eczema: clinical and aetiological types. Based on the guideline of the Danish Contact Dermatitis Group. Contact Dermatitis, 65(1), 13-21. Google Scholar

Karinda, M., Fatimawali, F., \& Citraningtyas, G. (2013). Perbandingan Hasil Penetapan Kadar Vitamin C Mangga Dodol Dengan Menggunakan Metode Spektrofotometri Uv-Vis Dan Iodometri. Pharmacon, 2(1). Google Scholar

Ketnawa, S., Chaiwut, P., \& Rawdkuen, S. (2012). Pineapple wastes: A potential source for bromelain extraction. Food and Bioproducts Processing, 90(3), 385-391. Google Scholar

Modi, G. M., Doherty, C. B., Katta, R., \& Orengo, I. F. (2009). Irritant contact dermatitis from plants. Dermatitis, 20(2), 63-78. Google Scholar

Rathnavelu, V., Alitheen, N. B., Sohila, S., Kanagesan, S., \& Ramesh, R. (2016). Potential role of bromelain in clinical and therapeutic applications. Biomedical Reports, 5(3), 283-288. Google Scholar 
Saary, J., Qureshi, R., Palda, V., DeKoven, J., Pratt, M., Skotnicki-Grant, S., \& Holness, L. (2005). A systematic review of contact dermatitis treatment and prevention. Journal of the American Academy of Dermatology, 53(5), 845-e1. Google Scholar

Schnuch, A., Geier, J., Lessmann, H., Arnold, R., \& Uter, W. (2012). Surveillance of contact allergies: methods and results of the I nformation $\mathrm{N}$ etwork of $\mathrm{D}$ epartments of D ermatology (IVDK). Allergy, 67(7), 847-857. Google Scholar

Slowdownik D, Lee A, dan N. R. (2008). Irritant contact dermatitis: A review. Australasian Journal of Dermatology, 49, 1-11.

Suryani, F. (2011). Faktor-faktor yang berhubungan dengan dermatitis kontak paa pekerja bagian prosessing dan filling Pt. cosmar Indonesia Tangerang Selatan tahun 2011. Google Scholar

Tayeb, R. H., Moradi, P., \& Soltani, F. (2013). The effect of nitrogen fixation and phosphorus solvent bacteria on growth physiology and vitamin $C$ content of Capsicum annum L. Google Scholar

Wasitaatmadja, S. M. (2018). Akne. Universitas Indonesia Publishing.Jakarta: Nonmencen Journal Of Medicine.

\section{Copyright holder:}

Enjelina, Dea Alnisrina, Lulu' Farida (2021)

First publication right:

Syntax Idea

This article is licensed under: 